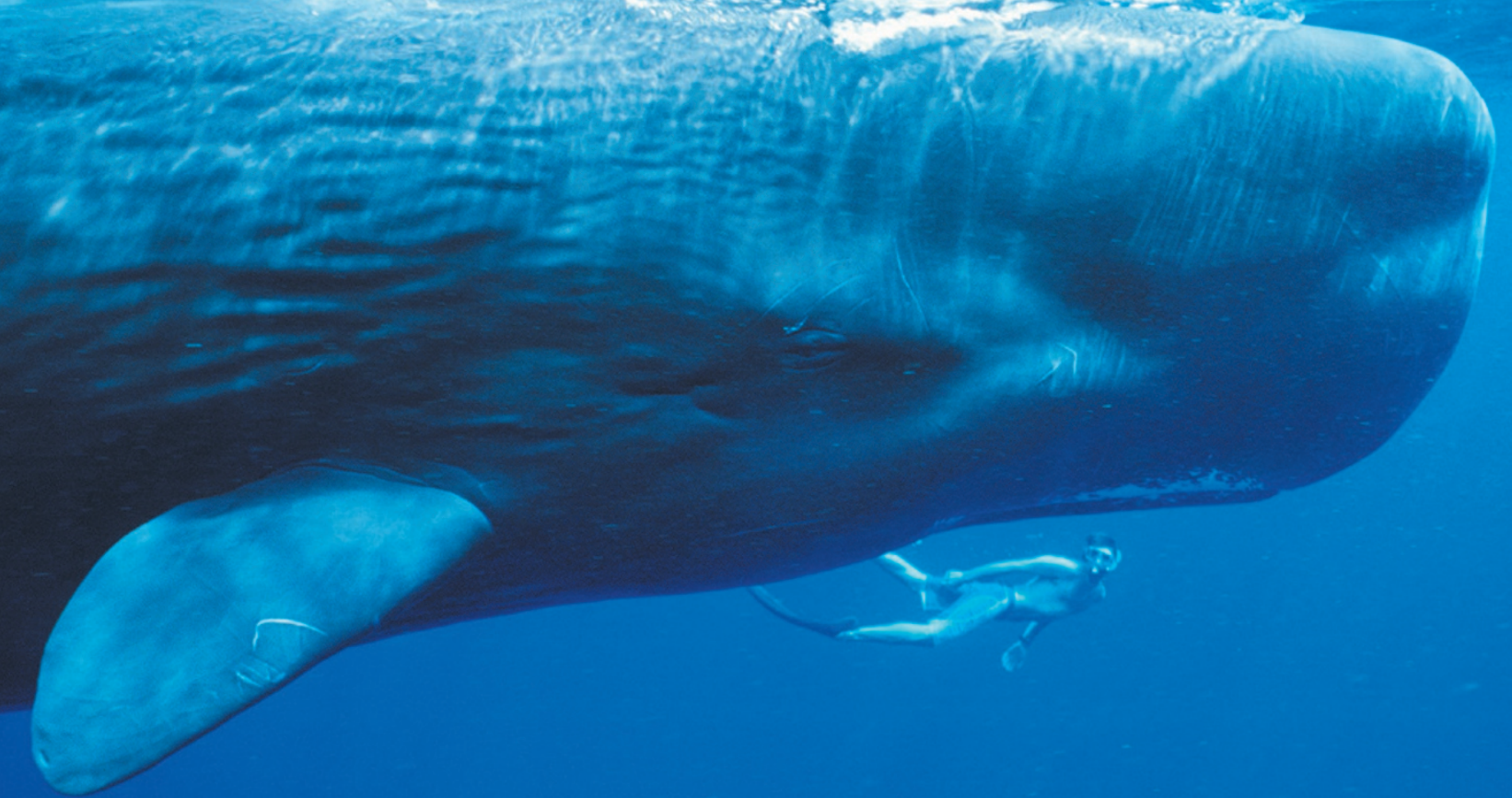

A sperm whale (Physeter macrocephalus) and a snorkeller in Caribbean waters.

NATURE WRITING

\title{
Cetacean subtleties
}

\section{Callum Roberts enjoys a celebration of the oceans and their largest denizens.}

I n December 2010, a whale and her calf beached and died on a remote stretch of New Zealand's Bay of Plenty. Two years later, the find was announced to the world as the first sighting of the planet's rarest cetacean. Mesoplodon traversii, the spadetoothed beaked whale, was previously known only from three skull fragments collected over 140 years from islands scattered across the South Pacific.

This whale is just one of many remarkable creatures that Philip Hoare describes in The Sea Inside - a beautifully written, impressionistic memoir of a seagoing life. The book is threaded through with ornithology, cetacean science, literature and a host of figures, from eighteenth-century medic and menagerie-keeper John Hunter to the eccentrics Hoare meets on his travels from England to New Zealand. Looking at a tideworn whale skull in the storeroom of the Te Papa museum in Wellington, Hoare imagines the creature alive in its ocean home, "striated and crisscrossed by innumerable scratches, as if subjected to cosmic strikes".

For me, nothing underlines the immensity of the world's oceans quite like this: that an animal roughly the size of a hippopotamus, surfacing to breathe many times a day, could have lived unseen for so long. But although the vastness of the oceans is central to planetary processes, it is no mark of invincibility. The human imprint can be found at the bottom of even the deepest abyss, where plastic bottles and tin cans lie incongruously alongside life forms so strange that they seem almost alien.

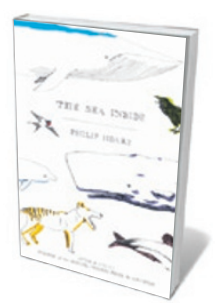

The Sea Inside PHILIP HOARE Fourth Estate: 2013. 384 pp. $£ 18.99$

\section{Hoare is acutely} aware of this vulnerability and worries about where the oceans and their inhabitants, many from ancient evolutionary lineages, are headed. His greatest love is cetaceans (he is author of the prizewinning Leviathan or, The Whale; Fourth Estate, 2008) and he describes the extraordinary lengths to which he has gone to swim with them in the wild: blue whales in Sri Lanka, Hector's dolphins in New Zealand, and Risso's dolphins and sperm whales in the Azores. These are vivid encounters. After days hanging at the surface in water more than 3,000 metres deep with a group of sperm whales, he learns to read their behaviour by subtle signs, just as "you can see in a person's eyes what they think of you long before they might put it into words". But Hoare acknowledges how hard it is to know what a whale thinks, because its senses are tuned differently from ours. We are hugely dependent on vision, whereas a whale relies far more on hearing in its underwater environment. Hoare contends that whales barrage of acoustic clicks allows them to probe solid bodies that have a similar density to water, much as a sonogram images a fetus. In a comment that floored me, he asserts that "a whale or dolphin can see the interior of my body as accurately as I can see the exterior of hers". Although plausible, I have not seen research that backs this up. It would be wonderful if it were true.

Slowly and unwittingly, humans have pushed some of the most spectacular and iconic species to the edge of extinction. Although a few still hover on the brink, many whale species - from humpback to bowhead - are making a comeback after decades of protection. Nobody celebrates the joy of their resurgence better than Hoare.

Callum Roberts is professor of marine conservation at the University of York, UK, and author of Ocean of Life: How our Seas are Changing.

e-mail:callum.roberts@york.ac.uk 